Proc. Estonian Acad. Sci. Biol. Ecol., 2003, 52, 2, 141-148

\title{
Seasonal variations in the grazing of Gammarus oceanicus, Idotea baltica, and Palaemon adspersus on benthic macroalgae
}

\author{
Helen Orav-Kotta ${ }^{\mathrm{a}, \mathrm{b} *}$ and Jonne Kotta ${ }^{\mathrm{a}}$ \\ ${ }^{a}$ Estonian Marine Institute, University of Tartu, Marja 4D, 10617 Tallinn, Estonia \\ ${ }^{\mathrm{b}}$ Institute of Zoology and Hydrobiology, University of Tartu, Vanemuise 46, 51014 Tartu, Estonia \\ Received 15 April 2002, in revised form 18 November 2002
}

\begin{abstract}
Grazing of Gammarus oceanicus, Idotea baltica, and Palaemon adspersus on benthic macroalgae was studied in situ using small enclosures in Kõiguste Bay, N Gulf of Riga. Pilayella littoralis was the prime diet of the studied invertebrates. When its biomass declined in the field, invertebrate grazing on Fucus vesiculosus increased. The highest grazing rates were shown by I. baltica followed by G. oceanicus and P. adspersus. In general invertebrate grazing was high in summer, moderate in autumn, and low in spring.
\end{abstract}

Key words: Baltic, Gammarus, grazing, Idotea, macrophytobenthos, Palaemon.

\section{INTRODUCTION}

Macroalgae are structurally and functionally important in coastal ecosystems. They are important primary producers (Mann, 1973; Smith, 1981; CharpyRoubaud \& Sournia, 1990) and a significant sink for anthropogenic carbon dioxide (Smith, 1981). Macrophyte communities are regulated both by nutrient loading and grazers' activity. The share of "bottom-up control" of "top-down" effects is thought to be highly variable between sites and seasons (e.g. Menge, 1992; Worm, 2000).

In recent decades, anthropogenic pollution has caused changes in plant biomasses and species composition in the whole coastal area of the Baltic Sea. The most drastic changes were the excessive growth of the filamentous macroalgae Pilayella littoralis (L.) Kjellm. and Cladophora glomerata (L.) Kütz. and the decline of perennial and slow growing Fucus vesiculosus L. (Kangas et al.,

* Corresponding author, helen@klab.envir.ee 
1982; Kautsky et al., 1986; Vogt \& Schramm, 1991; Kotta et al., 2000). This raised the question about the role of benthic grazers: do they buffer or amplify the effect of eutrophication? The grazers are potentially able to consume a significant proportion of the macroalgal production and, hence, control the blooms of filamentous algae. On the other hand, the grazers may selectively consume perennial algae, which in turn favours the development of fast growing species and destabilize the communities.

The evidence about the effect of invertebrate grazing on macroalgae is highly variable and controversial. The prevalent benthic herbivores inhabiting the northern Baltic Sea are omnivorous (Nicotry, 1980; Franke \& Janke, 1998) but they may be quite selective within food categories (Salemaa, 1978; Schaffelke et al., 1995). Besides, the effect of grazers has strong temporal and spatial variation (Kotta et al., 2000; Worm, 2000).

In the present study, in situ grazing rates of prevailing opportunistic herbivores on various macroalgal species were estimated in Kõiguste Bay, northern Gulf of Riga. The main questions were as follows: (1) which algal species are potentially consumed by selected invertebrates, (2) how large quantities of algae are removed by grazing, and (3) does seasonality affect the grazing pressure?

\section{MATERIAL AND METHODS}

In situ grazing experiments were performed in Kõiguste Bay $\left(58^{\circ} 22.10^{\prime} \mathrm{N}\right.$ $22^{\circ} 58.69^{\prime}$ E), northeastern Baltic Sea in April, July, and October 2001. Four different macroalgal species were deployed in the experiment: the brown algae $F$. vesiculosus and $P$. littoralis, the red alga Furcellaria lumbricalis (Huds.), and the green alga $C$. glomerata. The specimens of $F$. vesiculosus were divided into apical (juvenile) and basal (old) parts and treatments with $F$. vesiculosus overgrown with $P$. littoralis and epiphyte-free $F$. vesiculosus were distinguished. The use of different macroalgal treatments in different seasons depended on the natural occurrence of the algae in the field (Table 1).

Table 1. Different algal treatments used in the grazing experiment. Three replicates of each macroalgal treatment were used for each studied invertebrate species

\begin{tabular}{l|c|c|c}
\hline \multicolumn{1}{c|}{ Plant } & April & July & October \\
\hline Non-epiphytic Pilayella littoralis & + & + & \\
Basal Fucus vesiculosus without epiphytic Pilayella littoralis & + & + & + \\
Apical Fucus vesiculosus without epiphytic Pilayella littoralis & + & + & + \\
Basal Fucus vesiculosus with epiphytic Pilayella littoralis & + & + & \\
Apical Fucus vesiculosus with epiphytic Pilayella littoralis & + & & \\
Loose-lying Furcellaria lumbricalis & + & + & + \\
Attached Furcellaria lumbricalis & + & + & + \\
Cladophora glomerata & & + & \\
& & &
\end{tabular}


Idotea baltica (Pallas) and Gammarus oceanicus Segerstråle were collected from a shallow $(1-3 \mathrm{~m})$ area within the stands of $F$. vesiculosus by shaking the algae. Palaemon adspersus (Rathke) were caught by dredging the vegetated areas. Only adult specimens were used in the experiment.

Grazing was studied in $5 \times 5 \times 20 \mathrm{~cm}$ nylon netbags of $1 \mathrm{~mm}$ mesh size. When available in the field, each macroalgal treatment was added either two specimens of I. baltica, two specimens of G. oceanicus, or one specimen of P.adspersus. Three replicates of each treatment were used. The wet weight of algae was determined prior to the experiment to the nearest of $0.01 \mathrm{~g}$. Before weighing the algae were gently dried on plotting paper until the paper did not become wet any more. Additional three replicates of each macroalgal treatment served as control to obtain the ratio of wet to dry weight. The algae were dried at $60^{\circ} \mathrm{C}$ during $48 \mathrm{~h}$.

The netbags were placed at $2 \mathrm{~m}$ depth about $0.5 \mathrm{~m}$ above the bottom. Each series of the experiment lasted 10 days. In parallel to the grazing experiments, the in situ diurnal primary production of the studied macroalgal species was measured. Small tufts (ca. $0.05 \mathrm{~g} \mathrm{dw}$ ) with no macroepiphytes and grazers were placed in $600 \mathrm{~mL}$ glass bottles, filled with sea water, and incubated horizontally on special trays at $0.5 \mathrm{~m}$ depth. Bottles that did not include the algae served as controls. There were five replicates per each treatment and five controls (Kotta et al., 2000). Based on the production estimates, all macroalgal species were photosynthetically active and no decomposition of the macroalgae occurred.

At the end of the experiment the test animals were counted and the dry weights of invertebrates and macroalgae were determined. The changes in the dry weight of algae per dry weight of invertebrates in the nylon mesocosms served as the estimates of invertebrate grazing in the field. The grazing values were not compensated for the algal production in the present paper, as the production data were not yet fully available. However, earlier estimates (Kotta et al., 2000; Paalme et al., 2002) suggest that invertebrate grazing exceeds manifold the algal production in similar experimental design. Hence, the loss of algal material represents primarily invertebrate grazing.

\section{RESULTS}

The studied invertebrates consumed macroalgae the least in April when only I. baltica reduced the biomass of $P$. littoralis and the basal parts of $F$. vesiculosus overgrown with $P$. littoralis. The idoteid grazing in other macroalgal treatments was statistically insignificant. Similarly, the grazing of G. oceanicus and P. adspersus on the studied algae was negligible (ANOVA, $p>0.05$ ) (Fig. 1).

The highest grazing level was observed in July. G. oceanicus and I. baltica consumed more macroalgae than $P$. adspersus. Among the studied macrophytes 

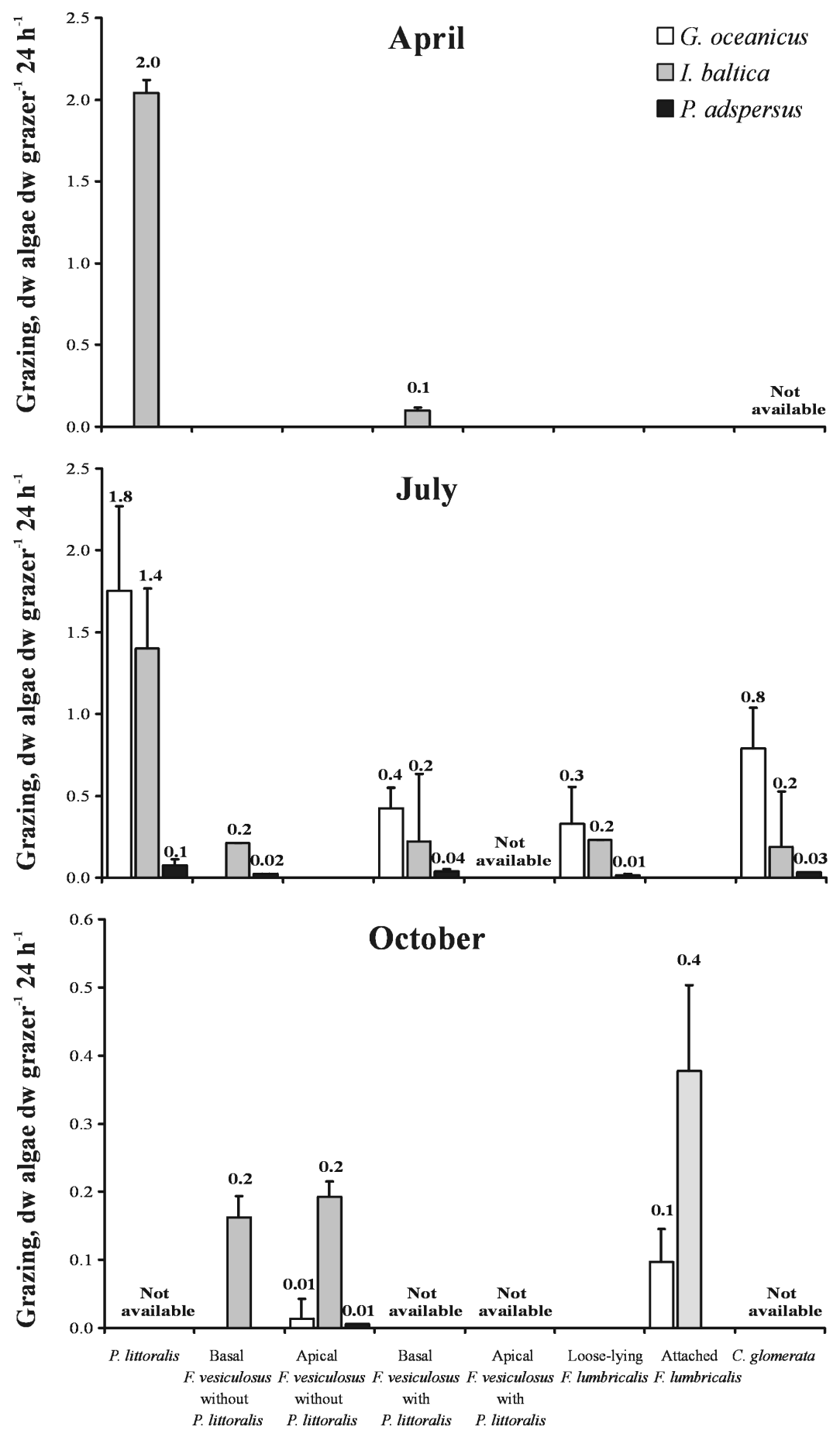

Fig. 1. Daily grazing of Gammarus oceanicus, Idotea baltica, and Palaemon adspersus on benthic macroalgae in April, July, and October. 
the consumption of the non-epiphytic $P$. littoralis was the highest followed by C. glomerata and the epiphytic P. littoralis. I. baltica and P. adspersus also consumed the basal parts of $F$. vesiculosus. All the studied invertebrates grazed more on the loose-lying than on the attached form of F. lumbricalis (Fig. 1).

In October the grazing was moderate, being about two times lower than in July. As a difference of the previous seasons the attached form of $F$. lumbricalis and the epiphyte-free $F$. vesiculosus were an attractive diet for invertebrates (Fig. 1).

\section{DISCUSSION}

Our study indicated that $P$. littoralis was the prime diet of the studied grazers in Kõiguste Bay. The consumption of $F$. vesiculosus was moderate when the biomass of $P$. littoralis was reduced in the field.

I. baltica is omnivorous, feeding on benthic microalgae, filamentous algae, macroalgae, detritus, small invertebrates, and even its conspecifics (Naylor, 1955; Sywula, 1964; Ravanko, 1969; Nicotry, 1980; Robertson \& Mann, 1980; Franke \& Janke, 1998). Despite its omnivory, I. baltica is rather selective within food categories (Salemaa, 1978; Schaffelke et al., 1995). Its dietary choice involves selection between different algal species (Schaffelke et al., 1995; Schramm et al., 1996) but likely also between different parts of the algal thallus (Salemaa, 1987). In the northern Baltic Sea, however, F. vesiculosus is considered the main source of food for I. baltica (Salemaa, 1987).

Earlier literature does not provide a definite answer to the question whether I. baltica select $F$. vesiculosus for shelter or food, as the experiments about the microhabitat choice of idoteids usually involved only a single macroalgal species (e.g. Salemaa, 1987; Merilaita \& Jormalainen, 2000). Our experiments indicated the prevalence of $P$. littoralis as a main food for I. baltica. In the absence of $P$. littoralis, I. baltica fed on $F$. vesiculosus and $C$. glomerata. Hence, in the light of these results, the former hypothesis is more likely.

Gammarids are considered selective omnivores. Their diet consists of decaying organic matter with its microbial community, macroalgae but also other animals such as other invertebrates, fish eggs, wounded fish (e.g. Macneil et al., 1997). The utilization of macrophytes is dependent on plant species, their condition, plant particle size, microbial activity on the plant material, and nutritional quality (Hutchinson, 1975; Wetzel, 1983). The growth of the limnic gammarids Gammarus fossarum Koch and Gammarus roeseli Gervais is affected by the type of diet, being high on naturally decaying leaves and fine organic detritus and low on green algae (Pöckl, 1995). Flesh supplements to an algal diet accelerate the growth and maturation of gammarids (Vassallo \& Steele, 1980).

Our study demonstrated that besides P. littoralis, Gammarus spp. consumed significant amounts of the green alga $C$. glomerata. An earlier study with the 
limnic gammarids showed that among a large variety of food, the growth and survival of the amhipods are poorest with Cladophora sp. (Pöckl, 1995). The difference between these observations might be attributed to the condition of Cladophora. Our earlier studies demonstrated that the attractiveness of Cladophora to invertebrate grazing is highly dependent on the physiological state of the filamentous algae (Paalme et al., 2002).

Palaemon spp. are omnivorous, feeding on algae, moss, debris, and small arthropods (Berglund, 1980). Other studies suggest the prevalence of carnivorous habits (Sitts \& Knight, 1979; Siegfried, 1982). Our study showed that $P$. adspersus consumed relatively high quantities of $P$. littoralis and basal parts of $F$. vesiculosus. However, the consumption rates were manifold lower as compared to I. baltica and Gammarus spp.

The results of this study give an indication of the invertebrate grazing in the study area. Our next step will be to combine the estimates of algal production and invertebrate densities with the grazing rates. This will allow us to detect whether benthic grazers are potentially able to regulate the macroalgae in the northern Baltic Sea.

\section{ACKNOWLEDGEMENTS}

The study was financed by the Estonian Governmental Programmes Nos. 0200792s98 and 0182578s03 and the Estonian Science Foundation grant No. 5103.

\section{REFERENCES}

Berglund, A. 1980. Niche differentiation between two littoral prawns in Gullmar Fjord, Sweden: Palaemon adspersus and P. squilla. Holarct. Ecol., 3, 111-115.

Charpy-Roubaud, C. \& Sournia, A. 1990. The comparative estimation of phytoplanktonic, microphytobenthic and macrophytobenthic primary production in the oceans. Mar. Microb. Food Webs, 4, 31-57.

Franke, H.-D. \& Janke, M. 1998. Mechanisms and consequences of intra- and interspecific interference competition in Idotea baltica (Pallas) and Idotea emarginata (Fabricius) (Crustacea: Isopoda): a laboratory study of possible proximate causes of habitat segregation. J. Exp. Mar. Biol. Ecol., 227, 1-21.

Hutchinson, G. E. 1975. A Treatise on Limnology. III. Limnological Botany. Wiley Interscience, New York.

Kangas, P., Autio, H., Hällfors, G., Luther, H., Niemi, A. \& Salemaa, H. 1982. A general model of the decline of Fucus vesiculosus at Tvärminne, south coast of Finland in 1977-1981. Acta Bot. Fenn., 118, 1-27.

Kautsky, N., Kautsky, H., Kautsky, U. \& Waern, M. 1986. Decreased depth penetration of Fucus vesiculosus (L.) since 1940's indicates eutrophication of the Baltic Sea. Mar. Ecol. Prog. Ser., 28, 1-8. 
Kotta, J., Paalme, T., Martin, G. \& Mäkinen, A. 2000. Major changes in macroalgae community composition affect the food and habitat preference of Idotea baltica. Int. Rev. Hydrobiol., 85, 697-705.

Macneil, C., Dick, J. T. A. \& Elwood, R. W. 1997. The trophic ecology of freshwater Gammarus spp. (Crustacea: Amphipoda): problems and perspectives concerning the functional feeding group concept. Biol. Rev., 72, 349-364.

Mann, K. H. 1973. Seaweeds: their productivity and strategy for growth. Science, 182, 975-981.

Menge, B. A. 1992. Community regulation: under what conditions are bottom-up factors important on rocky shores? Ecology, 73, 755-765.

Merilaita, S. \& Jormalainen, V. 2000. Different roles of feeding and protection in diel microhabitat choice of sexes in Idotea baltica. Oecologia, 122, 445-451.

Naylor, E. 1955. The ecological distribution of British species of Idotea (Isopoda). J. Anim. Ecol., 24, 255-269.

Nicotry, M. E. 1980. Factors involved in herbivore food preference. J. Exp. Mar. Biol. Ecol., 42, 13-26.

Paalme, T., Kukk, H., Kotta, J. \& Orav, H. 2002. "In vitro" and "in situ" decomposition of nuisance macroalgae Cladophora glomerata and Pilayella littoralis. Hydrobiologia, 475/476, 469476.

Pöckl, M. 1995. Laboratory studies on growth, feeding, moulting and mortality in the freshwater amphipods Gammarus fossarum and G. roeseli. Arch. Hydrobiol., 134, 223-253.

Ravanko, O. 1969. Benthic algae as food for some invertebrates in the inner part of the Baltic. Limnologica, 7, 203-205.

Robertson, A. I. \& Mann, K. H. 1980. The role of isopods and amphipods in the initial fragmentation of eelgrass detritus in Nova Scotia, Canada. Mar. Biol., 59, 63-69.

Salemaa, H. 1978. Geographical variability in the colour polymorphism of Idotea baltica (Isopoda) in the northern Baltic. Hereditas, 88, 165-182.

Salemaa, H. 1987. Herbivory and microhabitat preferences of Idotea spp. (Isopoda) in the northern Baltic Sea. Ophelia, 27, 1-15.

Schaffelke, B., Evers, D. \& Walhorn, A. 1995. Selective grazing of the isopod Idotea baltica between Fucus evanescens and F. vesiculosus from Kiel Fjord (western Baltic). Mar. Biol., 124, 215-218.

Schramm, W., Lotze, H. K. \& Schories, D. 1996. Eutrophication of macroalgal blooms in inshore waters of the German Baltic coast: the Schlei Fjord, a case study. EUMAS synthesis report, NIOO, Yerseke, The Netherlands.

Siegfried, C. A. 1982. Trophic relations of Crangon franciscorum Stimpson and Palaemon macrodactylus Rathbun: predation on the opossum shrimp, Neomysis mercedis Holmes. Hydrobiologia, 89, 129-139.

Sitts, R. M. \& Knight, A. W. 1979. Predation by the estuarine shrimps Crangon franciscorum Stimpson and Palaemon macrodactylus Rathbun. Biol. Bull., 156, 356-368.

Smith, S. V. 1981. Marine macrophytes as a global carbon sink. Science, 211, 838-840.

Sywula, T. 1964. A study on the taxonomy, ecology and geographical distribution of species of genus Idotea Fabricus (Isopoda, Crustacea) in Polish Baltic. 1 and 2. Bull. Soc. Amis. Sci. Lettr. Poznana. Ser., D 4, 141-200.

Vassallo, L. \& Steele, D. H. 1980. Survival and growth of young Gammarus lawrenicus Bousfield, 1956, on different diets. Studies-On-Gammaridea 2. Suppl. 6, 118-125.

Vogt, H. \& Schramm, W. 1991. Conspicuous decline of Fucus in Kiel Bay (western Baltic): What are the causes? Mar. Ecol. Prog. Ser., 69, 189-194.

Wetzel, R. G. 1983. Limnology. 2nd ed. Saunders College Publishing, Philadelphia, Pennsylvania.

Worm, B. 2000. Consumer versus resource control in rocky shore food webs: Baltic Sea and Northwest Atlantic Ocean. Ber. Inst. Meereskd. Christian-Albrechts-Univ. Kiel, 316. 


\title{
Sesoonsed muutused Gammarus oceanicus'e, Idotea baltica ja Palaemon adspersus'e toitumisel makrovetikatest
}

\author{
Helen Orav-Kotta ja Jonne Kotta
}

Gammarus oceanicus'e, Idotea baltica ja Palaemon adspersus'e toitumisaktiivsust uuriti Kõiguste lahes, kasutades selleks nailonist mesokosme. Nimetatud selgrootud toitusid peamiselt pruunvetikast Pilayella littoralis. Kui selle vetika biomass uurimisalal vähenes, suurenes teise pruunvetika (Fucus vesiculosus'e) tähtsus selgrootute toidus. Kõige suurema koguse vetikatest tarbis I. baltica, järgnesid G. oceanicus ja $P$. adspersus. Üldjuhul oli selgrootute toitumisintensiivsus suurim suvel, keskmine sügisel ning vähim kevadel. 